\title{
SOIL AMENDING AS A MANAGEMENT PRACTICE FOR MINIMIZING BICARBONATE HAZARD OF SALINE IRRIGATION WATER
}

\author{
Abdel-Aal, R. S. *; M. D. Alaga ${ }^{* *}$; A. H. Abd El-Hamid ${ }^{\star *}$ and
}

A. A. Mousa ${ }^{* *}$

* Soil Sci. Dept., Faculty of Agric., Moshtohor, Benha Univ., Egypt

"Soil Conservation. Dept., Desert Res. Centre Cairo, Egypt

\begin{abstract}
In order to evaluate the effect of bicarbonate ions in saline irrigation water in Ras Sudr Research Station where calcareous and sandy loam textured soil is dominant. Four levels of bicarbonate (initial level of well water 2.5, 5, 10, and 15 meqL $\left.\mathrm{L}^{-1}\right)$, different additions of farmyard manure $\left(0,10\right.$, and $\left.20 \mathrm{~m}^{3} \mathrm{fed}^{-1}\right)$ and three rates of sulphur $\left(0,250\right.$ and $\left.500 \mathrm{~kg} \mathrm{~S} \mathrm{fed}^{-1}\right)$. The obtained data revealed that both soil EC and soil $\mathrm{pH}$ increased with increasing bicarbonate concentration more than $5 \mathrm{meqL}^{-1}$ in irrigation water. However soil EC and $\mathrm{pH}$ were decreased with increasing FYM and or sulphur rates. Soluble $\mathrm{Na}^{+}$and $\mathrm{K}^{+}$were increased with increasing $\mathrm{HCO}_{3}$ concentration, in irrigation water but soluble $\left(\mathrm{Ca}^{++} \& \mathrm{Mg}^{++}\right)$were lowest in case of $(5$ meqL $\left.\mathrm{L}^{-1} \mathrm{HCO}_{3}{ }^{-}\right)$. The effect of $\mathrm{FYM}$ and $\mathrm{S}$ were clear in case of $\mathrm{OM}_{2} \mathrm{~S}_{2}$. The low value of soluble chloride occurred with adding $10 \mathrm{~m}^{3}$ fed-1under $\mathrm{HCO}_{3}^{-}$rates 2.5 and 5 $\mathrm{meqL}^{-1}$. Farmyard manure of $10 \mathrm{~m}^{3} \mathrm{fed}^{-1}$ was the best treatment, which improved the leaching of sulphate salts.
\end{abstract}

Keywords: Farmyard manure, calcareous soil, saline condition, South Sinai.

\section{INTRODUTION}

In Egypt, calcareous soils comprise about $25 \%$ of the newly reclaimed area. Because of the limited sources of water supply and the need urgent to expend the agricultural land, the use of saline water irrigation may arise as obligatory solution for such problem.

Karam (1999) evaluated the effects of saline irrigation water on soil salinity in experiment comprising clay and loamy soils. He used three different salinity levels. Under these conditions, the leaching fraction of $30 \%$ through the low quality water consumption period, reduced the impacts of saline irrigation on both clay and loam soils.

Aziz et al., (1998) found that soil conditioning markedly increased the amount of total soluble salts. Sodium and chloride ions showed highest values, while the lowest ones were for $\mathrm{Mg}^{++}$and $\mathrm{K}^{+}$. They added that

Soluble cations under the conditions of longer irrigation interval followed the order: $\mathrm{Na}^{+}>\mathrm{Ca}^{+2}>\mathrm{Mg}^{+2}>\mathrm{K}^{+}$and $\mathrm{Cl}^{-}>\mathrm{HCO}_{3}^{-}>\mathrm{SO}^{-2}$.

EL-Maghraby (1997) reported that the results pertaining soil properties were affected by applying soil conditioners under 7 days' irrigation intervals. The soil $\mathrm{pH}, \mathrm{EC}$, SAR and ESP values were decreased with different magnitude under the conditioners treatments at any irrigation frequency. Also the waters table aggregates, soil moisture retention as measured at field capacity. While the bulk density decreased. Moreover, EL-Nabulsi (1998) showed that the $\mathrm{EC}_{\mathrm{e}}$ and $\mathrm{SAR}$ increased noticeably as irrigation water salinity 
increased, reducing the irrigation frequency prevented salt build up the soil. A direct positive relationship was observed also between water salinity and the leached fraction. The average soil EC $\mathrm{E}$ in the $0-90 \mathrm{~cm}$ depth showed a distinct response to water salinity and irrigation frequency.

Also, FYM decomposition produces different acids which decrease soil $\mathrm{pH}$. The lowest value in soluble $\mathrm{Na}^{+}$through bicarbonate concentration of 5 meq $\mathrm{L}^{-1}$. The bicarbonate reduced plant yield:

a. The adverse effect of $\mathrm{HCO}_{3}{ }^{-}$on plant metabolic processes.

b. The disturbance on the plant nutrient balance.

c. The excess of bicarbonate induced the dominance ions which react with soluble $\mathrm{Zn}^{+2}$ in soil. From the previous mentioned we must use soil conditioners example sulphur and farmyard manure in Egypt, calcareous soil represents $25 \%$ of new reclaimed area.

El-Maghraby et al., (1996) stated that grain and straw yields were significantly increased as result of adding sulphur and FYM the best treatment was $500 \mathrm{~kg} \mathrm{fed}^{-1}$ from sulphur.

Therefore, this study aims to evaluate the effects of wheat cultivation, different additions of farm yard manure and sulphur on some soil properties of calcareous soil at Ras Sudr, South Sinai, Egypt.

\section{MATERIALS AND METHODS}

A field experiment was carried out during (1999-2000) and (200-2001) growing seasons at Ras Sudr Experimental Station. Desert Research Center, South Sinai using wheat (Sakha 8). This field trial was arranged in a split-split plot design with four replicates for each treatment.

The bicarbonate levels in irrigation water at $(2.5,5,10$ and15 meqL-1) were in the main plots. Sub plots were occupied by 3 treatments of farmyard manure (control, $10 \mathrm{~m}^{3} \mathrm{fed}^{-1}$ and $\left.20 \mathrm{~m}^{3} \mathrm{fed}-1\right)$. In addition, sub-sub plots were assigned by three rates of sulphur $\left(0,250\right.$ and $500 \mathrm{Kg} \mathrm{S}$ fed $\left.^{-1}\right)$.

The field experiment repeated for studding the response and residual effect through (2000-2001) growing season.

Soil analyses: Three soil samples representing three soil depths $0-15,15$ 30 and $30-45 \mathrm{~cm}$ were taken (Tables 1 and 2). The mechanical analysis was carried out using the pipette method (Piper, 1950). O.M\%, pH, EC dSm ${ }^{-1}$, soluble cations and anions also ESP were determined in soil samples as described by Jackson (1967) and Chapman and Pratt (1961).

Table 1: Some physical properties of the experimental soils at Ras sudr.

\begin{tabular}{|c|c|c|c|c|c|c|c|c|c|c|}
\hline $\begin{array}{c}\text { Soil } \\
\text { depth } \\
\text { (cm) }\end{array}$ & $\begin{array}{c}\text { Particle size distribution (\%) } \\
\text { Soarse }\end{array}$ & $\begin{array}{c}\text { Fine } \\
\text { Sand }\end{array}$ & Silt & Clay & $\begin{array}{c}\text { Texture } \\
\text { class }\end{array}$ & $\begin{array}{c}\text { Bulk } \\
\text { density } \\
\left(\mathbf{g} / \mathbf{c m}^{3}\right)\end{array}$ & $\begin{array}{c}\text { Field } \\
\text { capacity } \\
(\%)\end{array}$ & $\begin{array}{c}\text { Wilting } \\
\text { point } \\
(\%)\end{array}$ & $\begin{array}{c}\text { Av. } \\
\text { water } \\
(\%)\end{array}$ & $\begin{array}{c}\text { Caco } \\
(\%)\end{array}$ \\
\hline $0-15$ & 39.45 & 39.69 & 8.46 & 12.40 & Sandy loam & 1.44 & 18.90 & 9.52 & 50.90 & 50.90 \\
\hline $15-30$ & 37.20 & 43.31 & 12.22 & 7.27 & Sandy loam & 1.53 & 17.80 & 10.48 & 61.56 & 61.56 \\
\hline $30-45$ & 37.40 & 42.22 & 13.10 & 7.28 & Sandy loam & 1.52 & 17.30 & 10.63 & 51.32 & 51.32 \\
\hline
\end{tabular}


Table 2: Some chemical properties of the experimental soils at Ras sudr.

\begin{tabular}{|c|c|c|c|c|c|c|c|c|c|c|}
\hline \multirow{2}{*}{$\begin{array}{l}\text { Soil } \\
\text { depth } \\
\text { (cm) }\end{array}$} & \multirow{2}{*}{$\mathrm{pH}$} & \multirow{2}{*}{$\begin{array}{c}\mathrm{EC} \\
\left(\mathrm{dSm}^{-1}\right)\end{array}$} & \multicolumn{3}{|c|}{$\begin{array}{c}\text { Soluble cations } \\
\left(\text { meqL }^{-1}\right)\end{array}$} & \multicolumn{4}{|c|}{$\begin{array}{c}\text { Soluble anions } \\
\left(\text { meq L }^{-1}\right)\end{array}$} & \multirow{2}{*}{ ESP } \\
\hline & & & $\begin{array}{l}\mathrm{Ca}^{+2}+ \\
\mathrm{Mg}^{+2}\end{array}$ & $\mathrm{Na}^{+}$ & $\mathbf{K}^{+}$ & $\mathrm{CO}_{3}=$ & $\mathrm{HCO}_{3}{ }^{-}$ & $\mathrm{Cl}^{-}$ & $\mathrm{SO}_{4}=$ & \\
\hline $0-15$ & 7.4 & 14.3 & 97.71 & $\mid 79.80$ & 0.01 & -- & 3.54 & 133.4 & 50.90 & 13.60 \\
\hline $15-30$ & 7.4 & 13.60 & 84.00 & 82.54 & \begin{tabular}{|l|}
0.01 \\
\end{tabular} & -- & 6.80 & 1.70 & 61.56 & 14.92 \\
\hline $30-45$ & 7.4 & 11.70 & 84.88 & 58.75 & 1.80 & -- & 5.16 & 74.97 & 51.32 & 10.75 \\
\hline
\end{tabular}

Well water irrigation, $\mathrm{EC}, \mathrm{pH}$, and soluble cations and anions were determined as previously mentioned in soil extracts and are given in Table 3.

Table 3: Analysis of the saline well water used for irrigation.

\begin{tabular}{|c|c|c|c|c|c|c|c|c|}
\hline \multirow{2}{*}{$\begin{array}{c}E C \\
\left(d^{-1} ~ m^{-1}\right)\end{array}$} & \multicolumn{3}{|c|}{ Soluble cations (meq L-1) } & \multicolumn{4}{|c|}{ Soluble anions (meq L-1) } & \multirow{2}{*}{ SAR } \\
\hline & $\mathrm{Ca}^{++}+\mathrm{Mg}^{++}$ & $\mathrm{Na}^{+}$ & $\mathrm{K}^{+}$ & $\mathrm{CO}_{3}=$ & $\mathrm{HCO}_{3}$ & $\mathrm{Cl}^{-}$ & $\mathrm{SO}_{4}=$ & \\
\hline 10.20 & 62.80 & 80.13 & 1.18 & -- & 2.50 & 81.90 & 39.60 & 10.70 \\
\hline
\end{tabular}

FYM analysis of total N, C, P, K, Fe, Mn and $\mathrm{Zn}$ were determined according to Jackson(1967), Frie et al., (1964) and Lindsay and Norvell (1978). The obtained data are given in Table 4.

Table 4: Analysis of the applied farmyard manure.

\begin{tabular}{|c|c|c|c|c|c|c|c|c|c|c|c|}
\hline \multirow[t]{2}{*}{$\begin{array}{c}E C \\
\left(\mathrm{dSm}^{-1}\right)\end{array}$} & \multirow[t]{2}{*}{$\mathrm{pH}$} & \multirow[t]{2}{*}{$\begin{array}{l}\text { O. C. } \\
(\%)\end{array}$} & \multirow{2}{*}{$\begin{array}{c}\text { Water } \\
\text { holding } \\
\text { capacity } \\
(\%)\end{array}$} & \multirow{2}{*}{\begin{tabular}{|c|} 
Total \\
$\mathrm{N}$ \\
$(\%)$ \\
\end{tabular}} & \multirow[t]{2}{*}{$\begin{array}{c}\mathrm{C} / \mathrm{N} \\
\text { (ratio) }\end{array}$} & \multirow[t]{2}{*}{$\begin{array}{c}\text { Total } \\
P \\
(\%)\end{array}$} & \multirow[t]{2}{*}{$\begin{array}{c}\text { Total } \\
\text { K } \\
(\%)\end{array}$} & \multirow[t]{2}{*}{$\begin{array}{c}\begin{array}{c}\text { Total } \\
\text { sulphate } \\
(\%)\end{array} \\
\text { (\%) }\end{array}$} & \multicolumn{3}{|c|}{$\begin{array}{c}\text { Total } \\
\text { micronutrients } \\
\left(\mathrm{mg} \mathrm{kg}^{-1}\right)\end{array}$} \\
\hline & & & & & & & & & $\mathrm{Fe}$ & Mn & $\mathrm{Zn}$ \\
\hline 34.9 & 7.3 & 20.3 & 180 & 1.52 & 13.4 & 0.92 & 1.48 & 1.24 & 212 & 127 & 98 \\
\hline
\end{tabular}

The statistical analysis of the obtained data was done according to the method described by Gomez and Gomez (1984) using LSD to compare the mean values of treatments.

\section{RESULTS AND DISCUSSION}

The main effect of FYM rates on soil salinity regardless of sulfur, bicarbonate levels and soil depth show that EC values were decreased with increasing organic manure rates, generally the values of soil salinity of without organic manure application were relating greeting then that at FYM application either by OM1or OM2 in both seasons (Table 5).

On the other hand, the main effect of sulphur level on soil salinity regard of $\mathrm{OM}, \mathrm{HCO}_{3}{ }^{-}$levels, and soil depth show that the values of soil salinity were decreased with increasing sulpher levels in both seasons. However, the soil salinity values were increased with increasing bicarbonate levels.

In the first and second seasons, soil salinity decreased with increasing soil depth under any levels of $\mathrm{FYM}$ or sulphur and $\mathrm{HCO}_{3}{ }^{-}$. In addition, increasing sulphur levels decreased soil salinity at any soil depths or any levels of $\mathrm{FYM}$ and $\mathrm{HCO}_{3}$. Meanwhile, soil salinity was increased with increasing FYM levels and bicarbonate at both soil depths. 
It is worthy to note that the remarkable positive effect of either FYM or sulphur application was only occurred under 2.5 and $5 \mathrm{meqL}^{-1} \mathrm{HCO}_{3}$ (first and second levels). This result may be attributed to the main effect of sulphur on soil $\mathrm{pH}$ during both seasons, especially at the $2^{\text {nd }}$ rate $\left(500 \mathrm{~kg} \mathrm{fed}^{-1}\right)$. This result could be supported by that obtained by Cifuentes et al. (1993).

The role of organic manure was enhancing the soil structure and leaching of soluble salts, while sulphur oxidation produces sulphate that reacts with $\mathrm{Ca}$ and consists gypsum which enhanced the soil structure and decreased soil pH too (Aziz et al., 1998).

Table 5: EC $\left(\mathrm{dSm}^{-1}\right)$ values of the investigated soil after wheat harvesting.

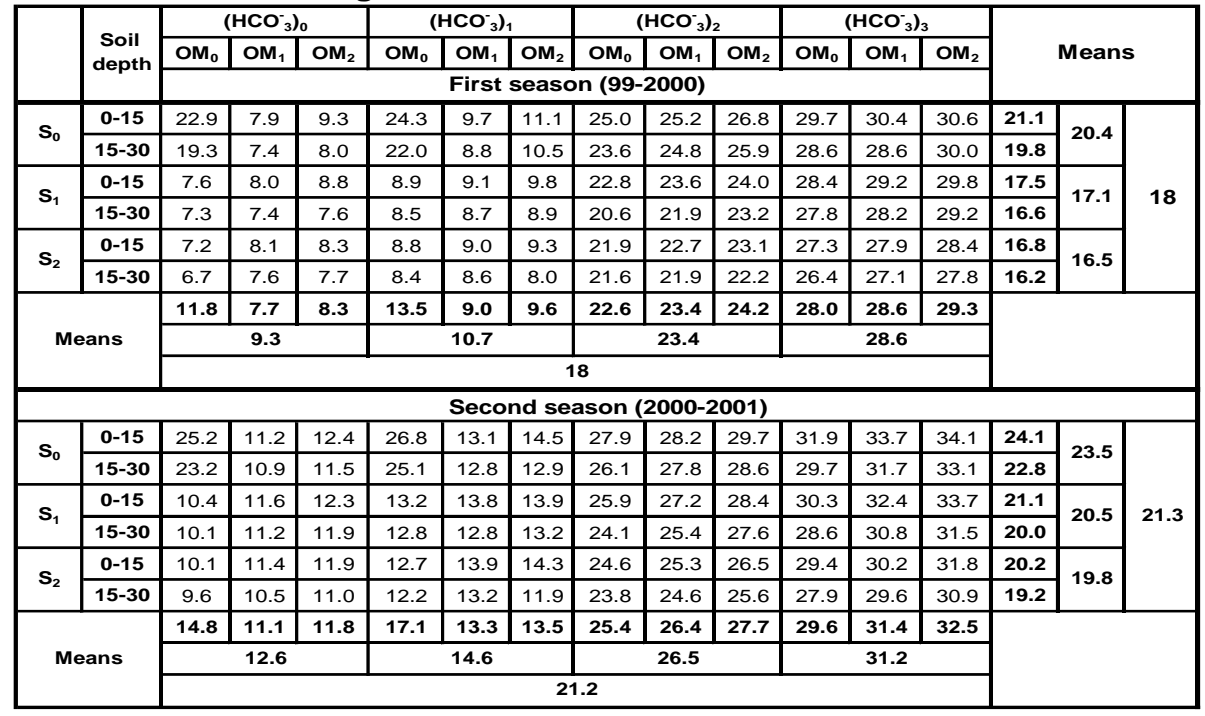

The values of $\mathrm{pH}$ as affected by the treatment under consideration are given in Table 6. It is clear that, the soil $\mathrm{pH}$ values were not remarkably affected by the treatments. In the same time the values of the second season are greater than that obtained in case of the first season.

The bicarbonate application changed the soil initial soluble $\mathrm{Na}^{+}$from 67.4 meqL ${ }^{-1}$ to 75.6 and 198.5 meqL $^{-1}$ due to the three rates of applied $\mathrm{HCO}_{3}$, respectively in the $1^{\text {st }}$ season (Table 7 ).

In the second season, the applied irrigation water which contains different levels of bicarbonates raised the general average of the soluble $\mathrm{Na}^{+}$ from $144.7 \mathrm{meqL}^{-1}$ to $158.15 \mathrm{meqL}^{-1}$.

Results reveal that, on average, sulphur application in the $1^{\text {st }}$ growth season reduced the soluble $\mathrm{Na}^{+}$seriously. The soluble $\mathrm{Na}^{+}$reduced was more clear in the upper $0-15 \mathrm{~cm}$ soil layer as compared to the $15-30 \mathrm{~cm}$ soil layer. On average, the soluble $\mathrm{Na}^{+}$values under $\mathrm{S}_{0}$ treatment $\left(166.5 \mathrm{meqL}^{-1}\right)$ was reduced to 137.1 and $130.5 \mathrm{meqL}^{-1}$ with sulfur application at rates of 250 and $500 \mathrm{~kg} \mathrm{fed}^{-1}$, respectively. However, for the $2^{\text {nd }}$ growth season there values were as, on average $(180,152$ and $142.3 \mathrm{meqL}^{-1}$ for $S_{0}, S_{1}$ and $S_{2}$, respectively at the $2^{\text {nd }}$ season while $S$ fed ${ }^{-1}$ 
respectively. Similar results were also obtained by El-Maghraby et al., (1996) showed that the $\mathrm{Na}^{+}$and $\mathrm{S}$ concentration were markedly affected by sulphur and organic manure applied singly or as combined treatments.

Table 6: The $\mathrm{pH}$ values of the investigated soil after wheat harvesting.

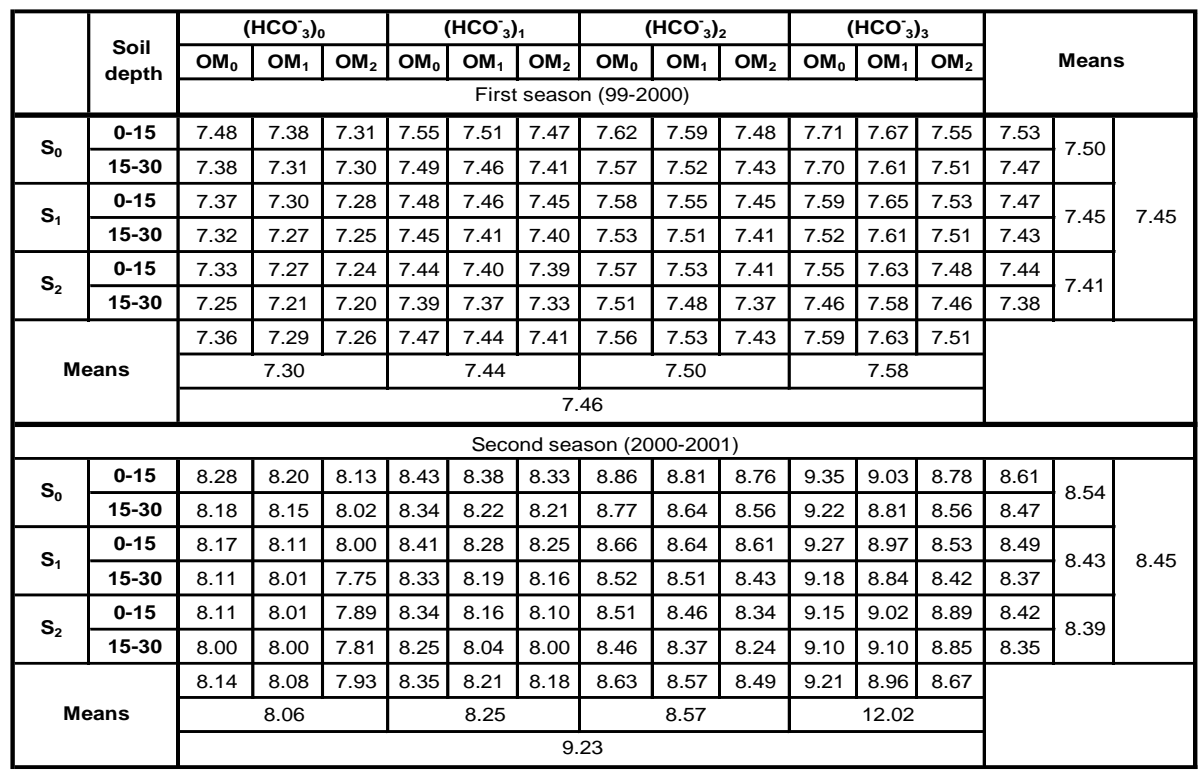

Table 7: Soluble $\mathrm{Na}^{+}\left(\mathrm{meqL}^{-1}\right)$ of the investigated soil after wheat harvesting.

\begin{tabular}{|c|c|c|c|c|c|c|c|c|c|c|c|c|c|c|c|c|}
\hline & \multirow{3}{*}{$\begin{array}{l}\text { Soil } \\
\text { depth }\end{array}$} & \multicolumn{3}{|c|}{$\left(\mathrm{HCO}_{3}^{-}\right)_{0}$} & \multicolumn{3}{|c|}{$\left(\mathrm{HCO}_{3}^{-}\right)_{1}$} & \multicolumn{3}{|c|}{$\left(\mathrm{HCO}_{3}^{-}\right)_{2}$} & \multicolumn{3}{|c|}{$\left(\mathrm{HCO}_{3}^{-}\right)_{3}$} & & \multirow{3}{*}{\multicolumn{2}{|c|}{ Means }} \\
\hline & & $\mathrm{OM}_{0}$ & $\mathrm{OM}_{1}$ & $\mathrm{OM}_{2}$ & $\mathrm{OM}_{0}$ & $\mathrm{OM}_{1}$ & $\mathrm{OM}_{2}$ & $\mathrm{OM}_{0}$ & $\mathrm{OM}_{1}$ & $\mathrm{OM}_{2}$ & $\mathrm{OM}_{0}$ & $\mathrm{OM}_{1}$ & $\mathrm{OM}_{2}$ & & & \\
\hline & & \multicolumn{12}{|c|}{ First season(99-2000) } & & & \\
\hline \multirow{2}{*}{$\mathrm{S}_{0}$} & $0-15$ & 186.2 & 52.5 & 68.3 & 198.5 & 68.4 & 75.2 & 211.4 & 214.2 & 229.2 & 239.9 & 247.8 & 253.9 & 170.5 & \multirow{2}{*}{166.5} & \multirow{6}{*}{144.7} \\
\hline & $15-30$ & 173.5 & 49.7 & 55.5 & 181.6 & 60.8 & 72.5 & 201.5 & 211.8 & 216.4 & 235.7 & 240.2 & 249.0 & 162.4 & & \\
\hline \multirow{2}{*}{$\mathbf{s}_{1}$} & $0-15$ & 51.5 & 58.2 & 61.6 & 59.6 & 62.8 & 68.5 & 191.4 & 201.4 & 203.3 & 234.1 & 240.2 & 248.0 & 140.1 & \multirow{2}{*}{137.1} & \\
\hline & $15-30$ & 49.2 & 51.7 & 52.8 & 53.6 & 56.3 & 61.4 & 182.8 & 198.7 & 200.0 & 228.0 & 233.0 & 242.0 & 134.1 & & \\
\hline \multirow{2}{*}{$S_{2}$} & $0-15$ & 48.6 & 53.3 & 57.9 & 59.1 & 54.3 & 66.7 & 180.7 & 192.1 & 195.9 & 227.7 & 231.2 & 233.0 & 133.4 & \multirow{2}{*}{130.5} & \\
\hline & $15-30$ & 47.2 & 48.6 & 47.8 & 51.6 & 49.6 & 59.6 & 177.3 & 180.6 & 184.3 & 225.0 & 229.0 & 230.0 & 127.6 & & \\
\hline \multirow{3}{*}{\multicolumn{2}{|c|}{ Means }} & 92.7 & 52.3 & 57.3 & 100.7 & 58.7 & 67.3 & 190.9 & 199.8 & 204.9 & 231.7 & 236.9 & 242.7 & & & \\
\hline & & & 67.4 & & & 75.6 & & & 198.5 & & & 237.1 & & & & \\
\hline & & \multicolumn{12}{|c|}{144.7} & & & \\
\hline \multicolumn{17}{|c|}{ Second season(2000-2001) } \\
\hline \multirow{2}{*}{$\mathrm{S}_{0}$} & $0-15$ & 193.3 & 75.9 & 87.9 & 200.4 & 89.7 & 110.5 & 226.5 & 229.7 & 240.5 & 250.4 & 258.6 & 268.9 & 186.0 & \multirow{2}{*}{180.0} & \multirow{6}{*}{158.1} \\
\hline & $15-30$ & 184.8 & 66.7 & 75.6 & 189.8 & 78.6 & 100.7 & 210.7 & 210.4 & 231.9 & 238.4 & 247.4 & 253.4 & 174.0 & & \\
\hline \multirow{2}{*}{$s_{1}$} & $0-15$ & 66.4 & 74.4 & 81.4 & 76.8 & 77.9 & 83.2 & 201.5 & 213.4 & 218.7 & 247.3 & 254.6 & 259.6 & 154.6 & \multirow{2}{*}{152.0} & \\
\hline & $15-30$ & 62.3 & 73.5 & 75.8 & 72.1 & 73.5 & 78.5 & 197.6 & 209.4 & 211.3 & 241.2 & 248.6 & 248.8 & 149.4 & & \\
\hline \multirow{2}{*}{$\mathrm{S}_{2}$} & $0-15$ & 57.6 & 63.5 & 75.4 & 67.4 & 69.5 & 74.4 & 191.3 & 204.5 & 209.4 & 231.6 & 244.3 & 246.1 & 144.6 & \multirow{2}{*}{142.3} & \\
\hline & $15-30$ & 53.4 & 60.4 & 72.4 & 66.9 & 64.5 & 71.5 & 188.4 & 194.5 & 196.7 & 229.1 & 241.0 & 240.5 & 139.9 & & \\
\hline \multirow{3}{*}{\multicolumn{2}{|c|}{ Means }} & 103.0 & 69.1 & 78.1 & 112.2 & 75.6 & 86.5 & 202.7 & 210.3 & 218.1 & 239.7 & 249.1 & 252.9 & & & \\
\hline & & & 83.4 & & & 91.5 & & & 210.4 & & & 247.3 & & & & \\
\hline & & \multicolumn{12}{|c|}{158.15} & & & \\
\hline
\end{tabular}


Under bicarbonate application at rates 2.5, 5, 10 and $15 \mathrm{meqL}^{-1}$, the soluble $\mathrm{K}^{+}$increased with increasing organic manure rates. The soluble $\mathrm{K}^{+}$values under $\mathrm{S}_{0}$ treatment $\left(3.9 \mathrm{meqL}^{-1}\right)$ increased to 5.4 and $5.7 \mathrm{meL}^{-1}$ with sulfur application at rates of $S_{1}, S_{2}$, respectively. Similar result was also obtained by El-Maghraby et al. (1996) (Table 8).

Table 8: Soluble $\mathrm{K}^{+}\left(\mathrm{meqL}^{-1}\right)$ of the investigeted soil after wheat harvesting.

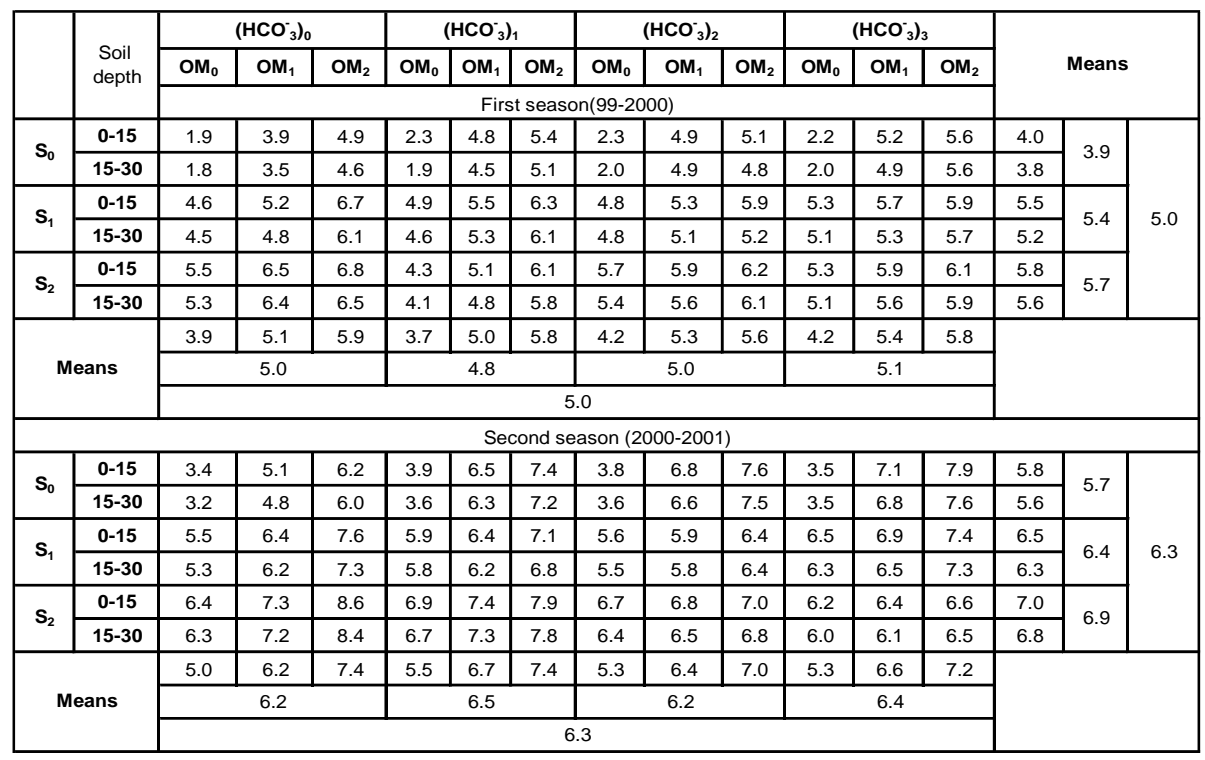

The bicarbonate application treatments increased the soil initial soluble $\left(\mathrm{Ca}^{++}+\mathrm{Mg}^{++}\right)$from $39,7 \mathrm{meqL}^{-1}$ to $49.0,103.8$ and $134.4 \mathrm{meqL}^{-1}$ due to the three rates of applied $\mathrm{HCO}_{3}$ respectively, at the $1^{\text {st }}$ growth season (Table 9).

The soluble $\left(\mathrm{Ca}^{++}+\mathrm{Mg}^{++}\right)$values were raised from 39.7, 49 to 103.8 and $134.4 \mathrm{meqL}^{-1}$ at the second growth season for the bicarbonate rates. The soluble $\left(\mathrm{Ca}^{++}+\mathrm{Mg}^{++}\right)$was reduced from $63.5 \mathrm{meqL}^{-1}$ to 38 and $45.4 \mathrm{meqL}^{-1}$ with $\mathrm{OM}_{1}$ and $\mathrm{OM}_{2}$ treatments, respectively in case of $\mathrm{HCO}_{3}\left(5 \mathrm{meqL}^{-1}\right)$ treatment under bicarbonate application of $\left(\mathrm{HCO}_{3}\right)_{2}$ and $\left(\mathrm{HCO}_{3}\right)_{3}$ increased the soluble $\mathrm{Ca}^{++}+$ $\mathrm{Mg}^{++}$under the $\mathrm{OM}_{1}$ and $\mathrm{OM}_{2}$ treatments. Result reveal that, on average, sulphur application at the $1^{\text {st }}$ growth season reduced the soluble $\mathrm{Ca}^{++}+\mathrm{Mg}^{++}$seriously. The soluble $\mathrm{Ca}^{++}+\mathrm{Mg}^{++}$reduction was more clear in the upper $0-15$ soil layer and lower through the $15-30 \mathrm{~cm}$ soil layer.

As for $2^{\text {nd }}$ growth season, on average, the value of soluble $\mathrm{Ca}^{++}+\mathrm{Mg}^{++}$ under $S_{0}$ treatment $\left(106.1 \mathrm{meqL}^{-1}\right)$ was reduced to 96 and $91.3 \mathrm{meqL}^{-1}$ with sulphur application at rates of $S_{1}$ and $S_{2}$ respectively. Similar results were also obtained by El-Maghraby et al. (1996).

The lowest values of soluble $\mathrm{Ca}^{++}+\mathrm{Mg}^{++}$were resulted from $\mathrm{OM}_{1} \mathrm{~S}_{2}$ under bicarbonate of $5 \mathrm{meqL}^{-1}$ and the highest value was obtained with $\mathrm{OM}_{2} \mathrm{~S}_{0}$ and bicarbonate of $15 \mathrm{meqL}^{-1}$ during both the $1^{\text {st }}$ season and $2^{\text {nd }}$ one . 
Table 9: Soluble $\left(\mathrm{Ca}^{++}+\mathrm{Mg}^{++}\right)($meq L-1) of the investigated soil after wheat harvesting.

\begin{tabular}{|c|c|c|c|c|c|c|c|c|c|c|c|c|c|c|c|c|}
\hline & \multirow{3}{*}{$\begin{array}{c}\text { Soil } \\
\text { depth }\end{array}$} & \multicolumn{3}{|c|}{$\left(\mathrm{HCO}_{3}\right)_{0}$} & \multicolumn{3}{|c|}{$\left(\mathrm{HCO}_{3}^{-}\right)_{1}$} & \multicolumn{3}{|c|}{$\left(\mathrm{HCO}_{3}\right)_{2}$} & \multicolumn{3}{|c|}{$\left(\mathrm{HCO}_{3}^{-}\right)_{3}$} & & \multirow{3}{*}{\multicolumn{2}{|c|}{ Means }} \\
\hline & & $\mathrm{OM}_{0}$ & $\mathrm{OM}_{1}$ & $\mathrm{OM}_{2}$ & $\mathrm{OM}_{0}$ & $\mathrm{OM}_{1}$ & $\mathrm{OM}_{2}$ & $\mathrm{OM}_{0}$ & $\mathrm{OM}_{1}$ & $\mathrm{OM}_{2}$ & $\mathrm{OM}_{0}$ & $\mathrm{OM}_{1}$ & $\mathrm{OM}_{2}$ & & & \\
\hline & & \multicolumn{12}{|c|}{ First season(99-2000) } & & & \\
\hline \multirow{2}{*}{$\mathbf{s}_{0}$} & $0-15$ & 102.5 & 38.9 & 40.9 & 109.8 & 45.3 & 56.1 & 114.6 & 116.3 & 124.5 & 137.9 & 139.7 & 142.9 & 97.5 & \multirow{2}{*}{95.0} & \multirow{6}{*}{81.7} \\
\hline & $15-30$ & 101.9 & 28.9 & 33.9 & 106.4 & 41.6 & 51.7 & 105.6 & 113.0 & 118.1 & 133.7 & 135.9 & 139.2 & 92.5 & & \\
\hline \multirow{2}{*}{$\mathbf{s}_{1}$} & $0-15$ & 28.3 & 32.2 & 38.8 & 43.2 & 38.2 & 44.9 & 97.6 & 107.1 & 110.2 & 133.9 & 138.4 & 140.5 & 79.4 & \multirow{2}{*}{77.1} & \\
\hline & $15-30$ & 26.8 & 28.9 & 31.5 & 41.4 & 35.9 & 41.9 & 88.3 & 93.0 & 106.3 & 130.2 & 135.6 & 138.2 & 74.8 & & \\
\hline \multirow{2}{*}{$\mathbf{S}_{2}$} & $0-15$ & 27.7 & 35.0 & 36.9 & 41.2 & 35.4 & 41.2 & 95.6 & 102.2 & 99.4 & 126.6 & 131.3 & 133.9 & 75.5 & \multirow{2}{*}{73.1} & \\
\hline & $15-30$ & 21.7 & 31.4 & 28.3 & 38.7 & 31.7 & 36.8 & 82.3 & 98.5 & 96.4 & 123.4 & 127.1 & 130.4 & 70.6 & & \\
\hline \multirow{3}{*}{\multicolumn{2}{|c|}{ Means }} & 51.5 & 32.6 & 35.1 & 63.5 & 38.0 & 45.4 & 97.3 & 105.0 & 109.2 & 131.0 & 134.7 & 137.5 & & & \\
\hline & & & 39.7 & & & 49.0 & & & 103.8 & & & 134.4 & & & & \\
\hline & & \multicolumn{12}{|c|}{81.7} & & & \\
\hline \multicolumn{17}{|c|}{ Second season(2000-2001) } \\
\hline \multirow{2}{*}{$\mathrm{S}_{0}$} & $0-15$ & 112.3 & 50.4 & 54.9 & 115.6 & 58.4 & 79.5 & 123.4 & 124.5 & 133.3 & 145.2 & 148.6 & 151.3 & 108.1 & \multirow{2}{*}{106.1} & \multirow{6}{*}{97.8} \\
\hline & $15-30$ & 109.5 & 41.3 & 56.8 & 110.2 & 51.6 & 73.9 & 119.8 & 121.3 & 130.5 & 141.6 & 143.8 & 147.6 & 104.0 & & \\
\hline \multirow{2}{*}{$\mathbf{s}_{1}$} & $0-15$ & 55.3 & 61.5 & 67.5 & 70.5 & 72.5 & 75.4 & 100.4 & 115.1 & 121.3 & 146.2 & 147.5 & 151.3 & 98.7 & \multirow{2}{*}{96.0} & \\
\hline & $15-30$ & 51.4 & 55.6 & 62.4 & 62.5 & 67.4 & 69.3 & 94.6 & 109.6 & 116.5 & 141.3 & 142.6 & 145.8 & 93.3 & & \\
\hline \multirow{2}{*}{$\mathrm{S}_{2}$} & $0-15$ & 47.6 & 60.4 & 65.4 & 69.7 & 71.8 & 73.6 & 93.5 & 109.5 & 110.5 & 138.7 & 140.6 & 146.7 & 94.0 & \multirow{2}{*}{91.3} & \\
\hline & $15-30$ & 45.6 & 54.2 & 60.7 & 61.8 & 66.3 & 68.8 & 87.6 & 101.2 & 105.4 & 132.4 & 136.7 & 142.6 & 88.6 & & \\
\hline \multirow{3}{*}{\multicolumn{2}{|c|}{ Means }} & 70.3 & 53.9 & 61.3 & 81.7 & 64.7 & 73.4 & 103.2 & 113.5 & 119.6 & 140.9 & 143.3 & 147.6 & & & \\
\hline & & \multirow{2}{*}{\multicolumn{9}{|c|}{112.1}} & \multicolumn{3}{|c|}{143.9} & & & \\
\hline & & & & & & & & & & & & & & & & \\
\hline
\end{tabular}

The best treatments were $\mathrm{OM}_{2} \mathrm{~S}_{1}$ at $2.5 \mathrm{meqL}^{-1}$ bicarbonate in irrigation water followed by $\mathrm{OM}_{2} \mathrm{~S}_{2}$ at $5 \mathrm{meqL}^{-1}$ bicarbonate concentrations (Table 10).

Table 10: Soluble $\mathrm{HCO}_{3}{ }^{-}\left(\mathrm{meqL}^{-1}\right)$ of the investigated soil after wheat harvesting.

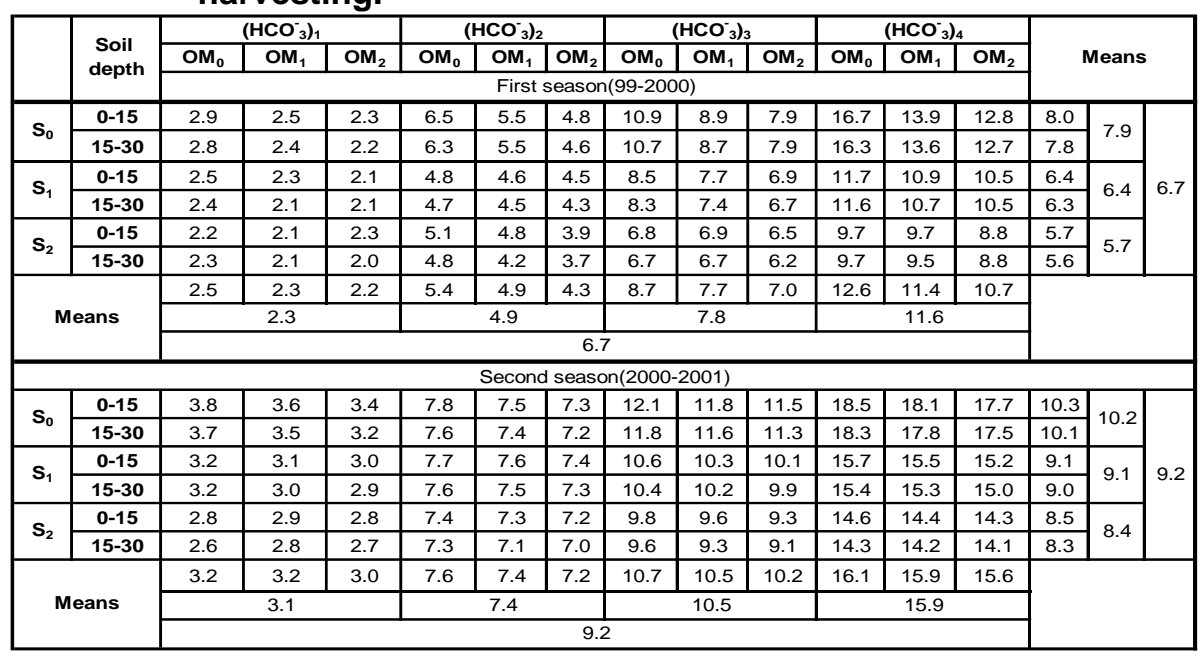

The best treatment of organic manure with respect to $\mathrm{Cl}^{-}$concentration was that of $10 \mathrm{~m}^{3} \mathrm{fed}^{-1}$. Under all the added bicarbonate concentrations but the $20 \mathrm{~m}^{3}$ fed $^{-1}$ rate was of the best one. However added $S$ up to $500 \mathrm{~kg} \mathrm{fed}^{-1}$ decreased the soil chloride concentration and the best treatment was $\mathrm{OM}_{1} \mathrm{~S}_{2}$ under all treatments of bicarbonate (Table 11). 
Abdel-Aal, R. S. et al.

Table 11: Soluble $\mathrm{Cl}^{-}\left(\mathrm{meqL}^{-1}\right)$ of the investigated soil after wheat harvesting.

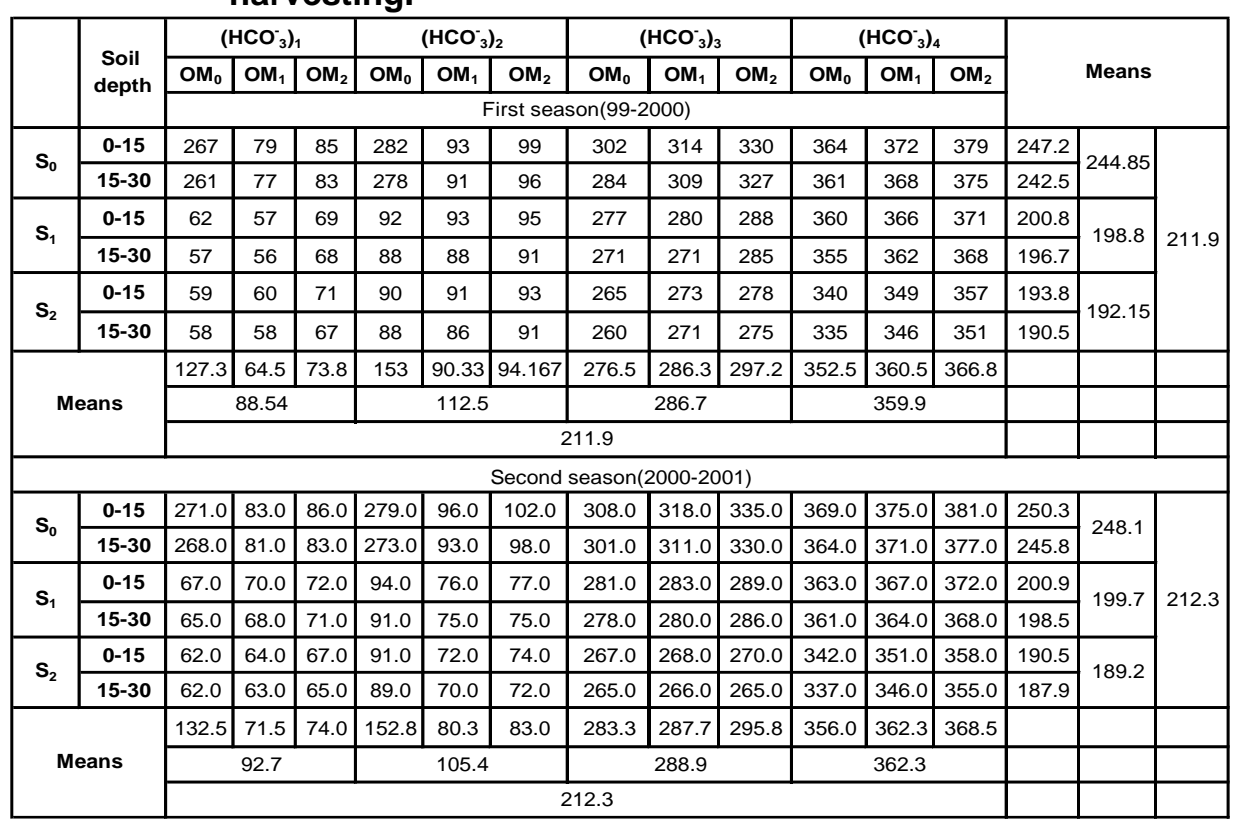

The rate of $10 \mathrm{~m}^{3} \mathrm{fed}^{-1} \mathrm{FYM}$ was the best treatment, inducing the leaching of sulfate salts. On the other hand, organic manure at the rate of 20 $\mathrm{m}^{3} \mathrm{fed}^{-1}$ increased the soluble sulfate. The best treatment was $\mathrm{OM}_{1} \mathrm{~S}_{2}$ under all the treatments of bicarbonate concentration (Table 12).

Table 12: Soluble $\mathrm{SO}_{4}^{--}\left(\mathrm{meqL}^{-1}\right)$ of the investigated soil after wheat harvesting.

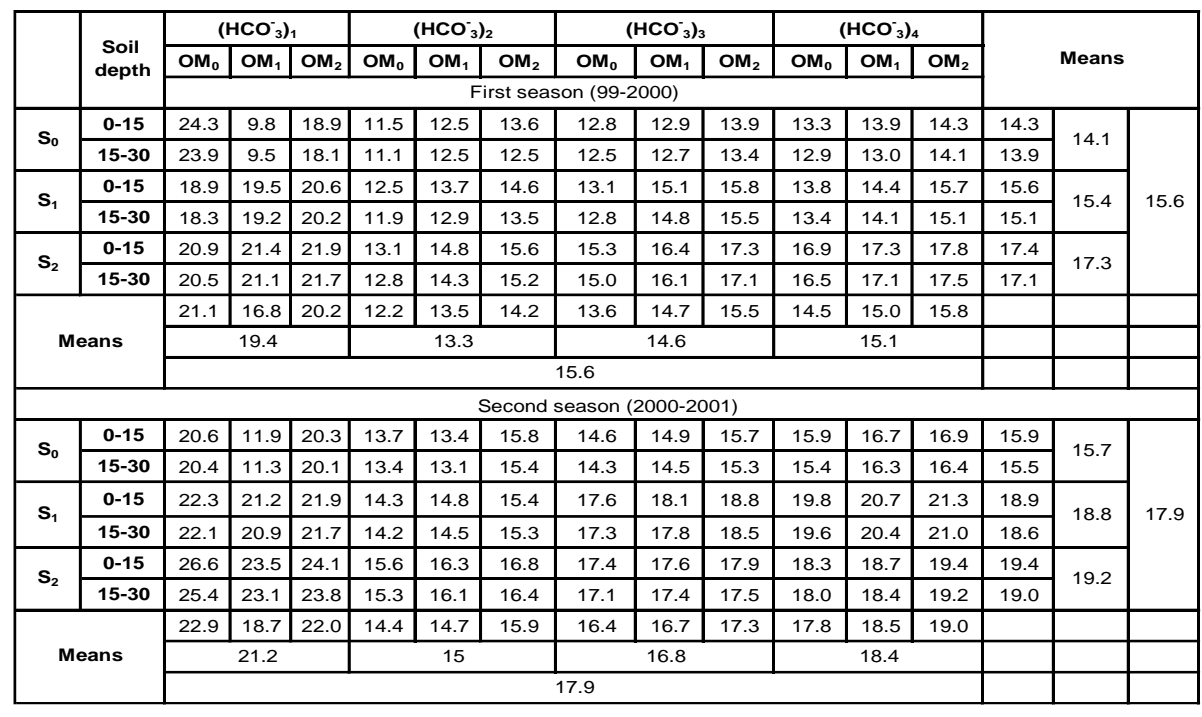




\section{Conclusion}

In conclusion, FYM and $\mathrm{S}$ tended to reduce the values of soil $\mathrm{EC}$ and $\mathrm{pH}$. The soluble $\mathrm{Na}^{+}, \mathrm{K}^{+}$and $\left(\mathrm{Ca}^{++}+\mathrm{Mg}^{++}\right)$were increased with increasing $\mathrm{HCO}_{3}{ }^{-}$ when the $\mathrm{HCO}_{3}^{-}$was more than $5 \mathrm{meqL}^{-1}$, but organic manure and sulphure reduced soluble $\mathrm{Na}^{+}, \mathrm{Ca}^{+}$and $\mathrm{Mg}^{++}$on contrast raised soluble $\mathrm{K}^{+}$. The effect of $\mathrm{S}$ as soluble anions was better than FYM. The best combined treatment in case of $\mathrm{OM}_{1}, \mathrm{OM}_{2}$ and $\mathrm{OM}_{3}$, respectively.

\section{REFERENCES}

Aziz, M. A., M. F. A. Sallam, A. M. El-Gendy and M.A. El-Moniem (1998). Effect of natural soil conditioners and irrigation conditions on some chemical properties of sandy soils of Inshas and cucumber yield.Egyptian Journal of Soil Science. 38:1-4, 377-411.

Chapman, H. D and D. F. Pratt (1961). Methods of Analysis for Soil. Plants and Water. Univ. of California, Division of Agric. Sciences.

Cifuentes, F. R and W. C. Lindemann (1993). Organic matter stimulation of elemental sulfur oxidation in a calcareous soil. Soil Science Society of America Journal. 57: (3) 727-731.

El-Maghraby, S. E. (1997). Impact of natural conditioners and saline irrigation water frequency on calcareous soil productivity. Egypt Soil Sci. 37:267281.

El-Maghraby, S. E. F. A. Hashem and M. M. Wassif (1996). The use of sulphur and organic manure for controlling soil salinity pollution under high saline water irrigation. Egyptian Journal of Soil Science. 36:1-4, 269-288.

El-Nabulsi, Y. A. (1998). Effect of saline water irrigation frequency and Crop on some soil chemical properties. Alxandria J. Agric. Res. 43: 255-265.

FAO (1985). Water Quality for Agriculture. Ayers R. S. and Westcott D. W. (Ed) irrigation and drainage. Paper 29, Rev. 1, FAO, Rome.

Frie, E.; K. Peyer and E. Schutg (1964). Determination of phosphorus by ascorbic acid. Schw. Lndwirtschaft, For Schung Heft. 3: 318-328.

Jackson, M. L. (1967). Soil Chemical Analysis Constable \& Co., Ltd., London.

Karam, F. (1999). The effect of saline irrigation water on sunflower production: assessment of leaching fraction for the control of root zone salinity. Irrigation management and saline condition. Proceedings of Regional Symposium. JUST, Irbid, Jordan, June. 98-107.

Lindsay and Norvell (1978). Development of a DTPA soil test for Fe, Mn, Zn and $\mathrm{Cu}$. Soil Sci. Amer. Proc. 42:421-428.

Gomez, K. A. and A. A. Gomez (1984). "Statistical Procedures for Agricultural Research". $2^{\text {nd }}$ Ed. John Wiely and Sons New York, pp. 680.Inc.

Piper, G. S. (1950). Soil and Plant Analysis. Interscience Publishers, Inc., New York. 
Abdel-Aal, R. S. et al.

استخدام مصلحات التربة كإحدى عمليات الخدمة للحد من مخاطر البيكربونـات فى

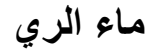

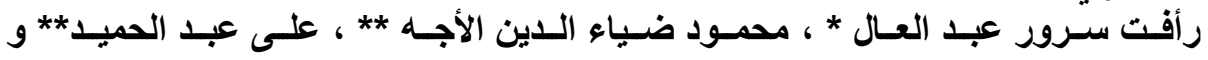

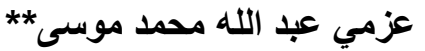

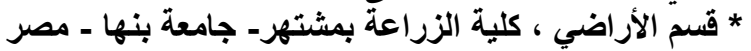

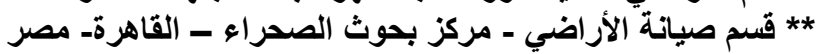

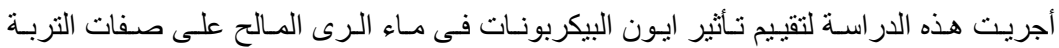

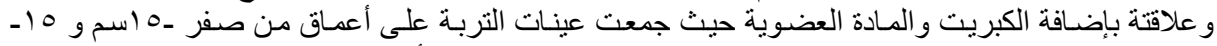

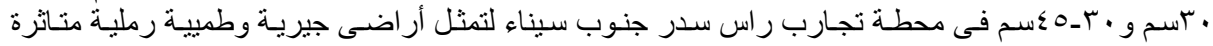

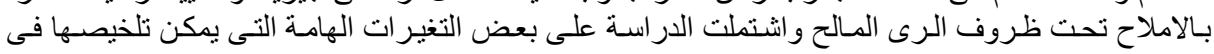

الاتى - التوصيل الكهربي: ازداد فى الطبقة السطحية وانخفض مع زيادة معدل اضافة المادة العضوية والكبريت.

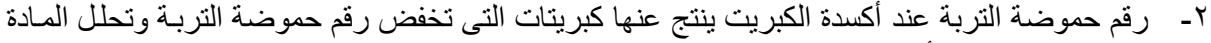

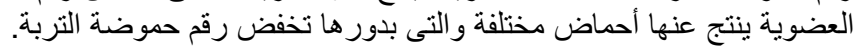

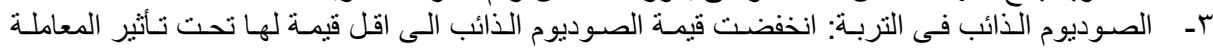

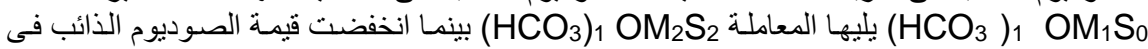
المعاملة

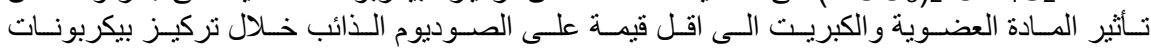

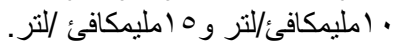

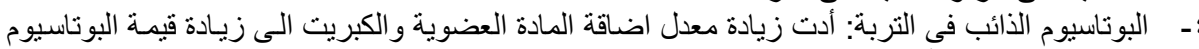

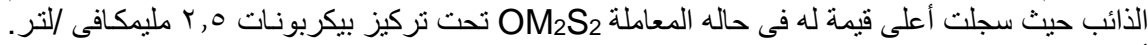
أخذت نركيز ات البوتاسيوم الترتيب الثنالى:

$\left(\mathrm{HCO}_{3}\right)_{1} \mathrm{OM}_{2} \mathrm{~S}_{2}>\left(\mathrm{HCO}_{3}\right)_{3} \mathrm{OM}_{2} \mathrm{~S}_{2}>\left(\mathrm{HCO}_{3}\right)_{2} \mathrm{OM}_{2} \mathrm{~S}_{2}=\left(\mathrm{HCO}_{3}\right)_{4} \mathrm{OM}_{2} \mathrm{~S}_{2}$

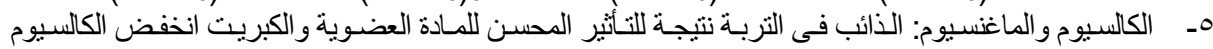

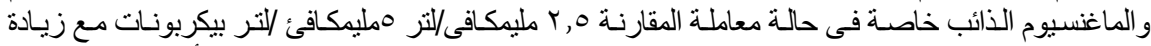

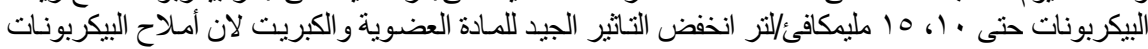

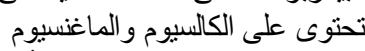

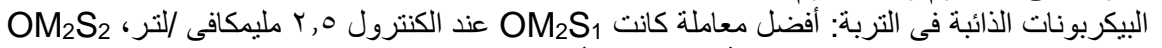

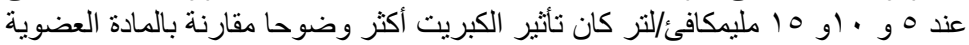

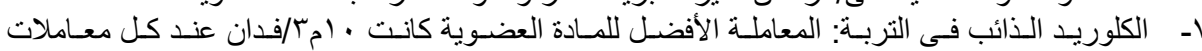

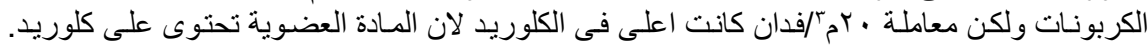
الكبريت نقص من تركيز الكلوريد مع زيادة معدلات الكبريت حتى الكي . . مكجم/فدان، المعاملة الأفضل كانت oM1 $S_{2}$

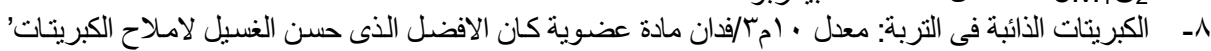

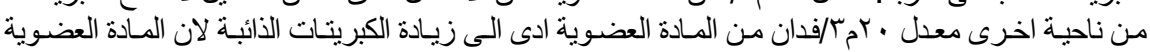
تحتوى على كبريتات، المعاملة الأفضل كانتٍ OM1S1 فى كل معاملات البيكربونات. 